\title{
18
}

\section{East of Easter: Traces of human impact in the far-eastern Pacific}

\author{
Iona Flett \\ Department of Archaeology and Natural History, Australian National University, Australia \\ iona.flett@anu.edu.au \\ Simon Haberle \\ Department of Archaeology and Natural History, Australian National University, Australia
}

\section{Introduction}

Building on the work of Atholl Anderson and other Pacific archaeologists, this paper describes the methodologies employed and some preliminary results in an ongoing investigation of preEuropean human impact on far-eastern Pacific Islands. Which islands in the far-eastern Pacific would Polynesian sailors have encountered if they ventured east of Easter Island? And if preColumbian South American explorers travelled west into the Pacific, would they have managed to reach the same islands? How would signals of human impact on these islands differ from signs of natural environmental variability? These questions form the basis of an investigation of the role played by the far-eastern Pacific Islands in the prehistoric trans-Pacific movement of people.

The islands considered in this investigation, and discussed below (Figure 1), include Isla Santa Maria, Isla Mocha, Chiloe, the Desventuradas group and the Juan Fernandez Islands, all annexed by Chile, the Galapagos Islands (Ecuador), and Cocos Island (Costa Rica). In contrast to other Pacific archipelagos, archaeologists have investigated the islands 'east of Easter' infrequently. These islands are much closer to the coast of mainland South America than they are to any of the known inhabited Polynesian islands, and some of them have American Indian archaeological sites. Historical occupation of these islands has been varied. The Chilean islands close to the coast were discovered by Europeans during exploration in the 15 th century. The Juan Fernandez group was discovered in 1575, Cocos in 1541, and the Galapagos Islands in 1535. The Juan Fernandez and the Galapagos groups were both used as shelters by whalers and buccaneers, and then were permanently settled by fishermen and pastoralists by the late 19th century.

Plausible circumstantial evidence, much of it related to the distribution of various cultivars, 


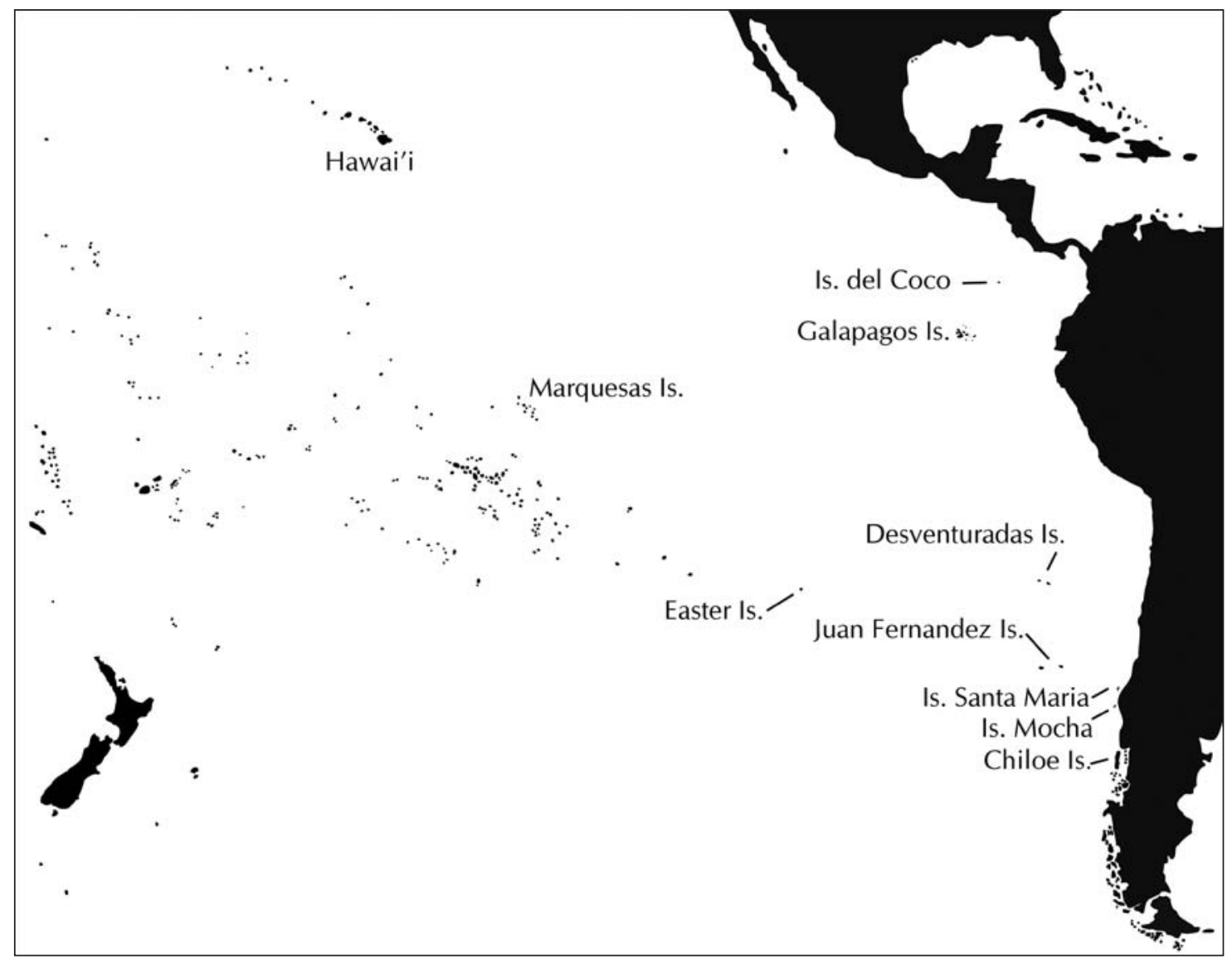

Figure 1. Map of the eastern Pacific with island groups referred to in the text.

has led to speculation that there was some contact in prehistory between Polynesians and West Coast South American Indians (Ballard 2005; Green 2005). The most widely cited evidence for the contact is the presence of the sweet potato (Ipomoea batatas) in Polynesia before European arrival. Regarded as a South American native, the sweet potato has been found in archaeological sites in the Pacific dating from before 1200 AD (Yen 1974; Hather and Kirch 1991; Green 2005). Since then, much cultural, linguistic, historical and archaeological evidence has been discussed in an attempt by scholars to determine how and when the sweet potato first arrived in the region. Green (2005) summarises the remaining questions: Did Polynesian sailors go to the Americas and retrieve it? Did South Americans take it to Easter Island, which became the dispersal origin? And do we still believe there had to have been human dispersal?

\section{Westward migration}

Montenegro et al. (2007) have recently conducted computer-simulation experiments modelling drifting of vessels and seeds west from South and Central America. This work updates previously published experiments by Levinson et al. (1973) and Irwin et al. (1990), by using more realistic oceanic and atmospheric current data, which are numerically modelled, rather than being probabilistically defined by localised observations (Montenegro et al. 2007). These recent simulations assume no input from human occupants of the rafts/floating debris (whereas the earlier models were designed to test likely voyaging routes), and allow many more points of exit from the American coasts than previously, thus simulating likely vegetation-dispersal scenarios independent of human coastal settlements. The authors conclude that with regard to the sweet potato, the central ellipse area proposed by Green (2005) and Yen (1974) is the most 
likely area for the plant's initial arrival into Polynesia, and an accidental drift voyage could have been responsible for the introduction (Montenegro et al. 2007). Interestingly, the results also indicate that hits to the Galapagos Islands both by floating vessels (influenced by wind and ocean currents) and other floating material (e.g. seed pods, influenced by ocean currents only) leaving from South and Central America have higher probabilities and faster voyaging times than hits on almost any other island.

Another Polynesian cultivar with an American origin is the bottle gourd (Lagenaria siceraria). Although there is an Asian variety, which was present in archaeological sites in Southeast Asia c. 5000 BP (Bellwood 1997), there is new phylogenetic evidence to support the hypothesis that the bottle gourd, like the sweet potato, was one of the cultivars obtained from the Americas (Clarke et al. 2006), where it was an early domesticate (Piperno et al. 2000). However, it should be noted that the American origins of some varieties of Polynesian bottle gourds do not necessarily imply human dispersal, since the authors note that seeds in the gourd may still be viable after up to seven months at sea (Clarke et al. 2006), and we know from the simulation experiments discussed above that floating material could feasibly arrive in Polynesia after leaving the American mainland in much less time (Montenegro et al. 2007).

Possible parallels have been observed between the Mapuche culture (of c. 1000 BC to present) in south-central Chile and Polynesia, in the form of some words, hand clubs similar to Maori clubs (patu), obsidian artefacts similar to those found in Polynesia, and sewn-plank canoes, although more information about the context and age of these finds is still required (Ramirez 1990/91; reference to Spanish text by Ramirez-Aliaga et al. 1992 in Anderson 2006). Earlier observations about a possible Asian influence on ancient Ecuadorian material culture (e.g. Gartelmann 1986:22-29) have been rejected by other authors, primarily because of the unlikelihood of successful Asia-to-Ecuador voyaging, rather than a lack of similarity between pottery styles or motifs (Bruhns 1994:361).

Heyerdahl's now debunked theory about South American colonisation of the Pacific Islands was based on South American indigenous oral histories, telling of a battle with a race of white Peruvians which was banished to the sea (Heyerdahl 1952; Terrell 1998; Holton 2004). His theory depended on the supposition that ocean-going sailing technology existed in South America before Europeans arrived, an issue which has been debated, for example by Suggs (1960:218), who writes, 'Although the Peruvians did use rafts to voyage off their coast long before the white men ever came, such rafts did not use sails, but were propelled by paddles.' Later, other authors have concluded that a South American vessel capable of reaching East Polynesia could have existed (e.g. Anderson 2006), and that prehistoric voyaging in any direction in the Pacific was probably relying on fair winds, some paddling and some drifting (Anderson et al. 2006). However, there is now cautious agreement among Pacific scholars that of the two groups, it was Polynesians who had the better navigation skills, and they could well have had the capability for deliberate voyaging to the coast of South America and back (Martinsson-Wallin and Crockford 2001; Anderson 2005; Anderson 2006), albeit mostly relying on downwind sailing (Anderson 2003).

\section{Eastward migration}

The best estimate for the time the colonising Lapita people moved into the west Pacific is currently c. 3300-2800 cal. BP (Anderson 2003; Hunt and Lipo 2006). After this, there seems to have been a pause before further expansion into central Micronesia and the marginal West Polynesian islands at about 2200-2000 cal. BP (Anderson et al. 2006:Figure 1). The initial colonisation of the Polynesian triangle, including Hawaii, the Marquesas, the Society Islands 
and the Cook Islands, was probably about 1250-1000 cal. BP (Anderson 2003; Anderson et al. 2006). New Zealand, Rapa, South Polynesia and the sub-polar region have no known signs of habitation until after 800 cal. BP (Anderson 1991; Anderson 2005; Kennett et al. 2006).

A question remains, however, about Easter Island. A 2001 review of the previously published radiocarbon chronologies rejected many of the early dates for the colonisation of Easter Island, and concluded colonisation occurred around the same time as the rest of East Polynesia, c. 1200-800 cal. BP (Martinsson-Wallin and Crockford 2001). Since then, Hunt and Lipo (2006) have argued that $1200 \mathrm{AD}$ (i.e. $800 \mathrm{BP}$ ) is the earliest acceptable date, and that the human population rapidly rose, with immediate impacts on the environment, identified from the palynological record. A later colonisation of Easter Island creates an interesting picture of the expansion to the outer edges of the Polynesian realm. It suggests that all the outermost southeastern islands, the Auckland Islands, New Zealand, Rapa, Mangareva and Easter Island, were colonised at virtually the same time. Given the massive distances being traversed in this region, it seems Polynesian exploration of the eastern Pacific was close to continuous between 1200 and 800 BP and exploration for new land and resources continued even during the expansion and settlement phase immediately after arrival at each new landfall.

A recent discovery on the coast of Chile provided evidence that this phase of oceanic exploration by Polynesians also resulted in contact with the South American mainland. Bones of the domestic chicken (Gallus gallus) were recovered in a prehistoric site called El Arenal-1, which TL dates on ceramics indicate was occupied between AD 700 and 1390 (Storey et al. 2007). One of the bones was dated to AD 1304-1424, and DNA sequencing from the same piece hinted that the chicken may have had a Polynesian genetic signature (Storey et al. 2007), although more recent analysis has exposed doubts about the DNA sequencing and further research is required (Gongora et al. 2008).

What, then, are the local climatic conditions which could have been affecting migration, ease of settlement and resource availability at this time? The idea at the centre of a paper by Anderson et al. (2006) is that the episodic nature of eastward dispersal in the Pacific might be related to the changing frequency of El Nino events. During a period of frequent El Nino activity there are likely to be more chances for eastward drifting or sailing, since the trade winds, which characteristically blow from east to west, weaken or fail during many ENSO events (Anderson et al. 2006). This viewpoint implies people were trying to voyage further and opportunistically used prevailing weather systems to do so; it does not consider the cultural or environmental reasons why they might have been voyaging. Patrick Nunn, in a variety of publications since 1998, has promoted the idea that increased precipitation and sea-level fall (due to atmospheric cooling) about AD 1300 had dramatic environmental effects, leading to changes in human settlement patterns, resource use and voyaging strategies, as well as increased conflict (Nunn and Britton 2001; Nunn 2003a,b).

While not all authors agree that the AD 1300 event was as catastrophic or as widespread as Nunn (2000) describes, there are a number of localised records in which there does appear to be some sort of perturbation about this time (Allen 2006). In addition, there are several central Pacific sites where there is evidence that the Medieval Warm Period (c. AD 900-1200) and the Little Ice Age (AD 1550-1900) had distinctive climatic signatures (Allen 2006). In the central Pacific, conditions during the Medieval Warm Period were apparently cool and dry, while the Little Ice Age seems to have been characterised by warm, wet and perhaps stormy conditions. Allen (2006) concludes her extensive review of the relevant research on this topic by noting that climate across the Pacific is, and has been, heterogeneous, and that the complex oceanatmosphere linkages lead to local-scale variability. For example, although much of the eastern 
Pacific is affected by increased sea-surface temperatures and rainfall during ENSO events, Easter Island is relatively unaffected (Genz and Hunt 2003). Given that exploration was apparently proceeding in the far-eastern Pacific during this period of climatic transition (and possibly upheaval) between 800 and 500 years ago, high-resolution palaeoclimate records over this time at a local scale are crucial. The Galapagos Islands, in their strategic position between the lands of eastern and western prehistoric navigators, are an ideal place to look for a window into the regional climate of the past 1000 years.

\section{Galapagos archaeology and palaeoecology to date}

The Galapagos Islands comprise 19 major islands and many smaller rocks and islets. They are orientated in a northwest-southeast direction, lying across the equator, about $1000 \mathrm{~km}$ west of Ecuador (Figure 1). The Galapagos Islands were formed between 0.3 million (westernmost islands) and 6 million (easternmost islands) years ago by volcanic activity at the Galapagos Hot Spot (Geist 1996). There are currently more than 20,000 permanent inhabitants (Gumbel 2005), living on five of the islands. The largest town, Peurto Ayora (Figure 2), is the hub of the islands' main industries, tourism and fishing. Their location between Easter Island and the South American mainland, along with the fact that the islands are the largest in the eastern Pacific and are known to have been a bountiful source of meat, fish and fresh water during the 18th and 19th centuries, has led to speculation that ancient seafarers might also have stopped in the Galapagos.

The Galapagos were devoid of obvious human habitation at the time of European arrival.

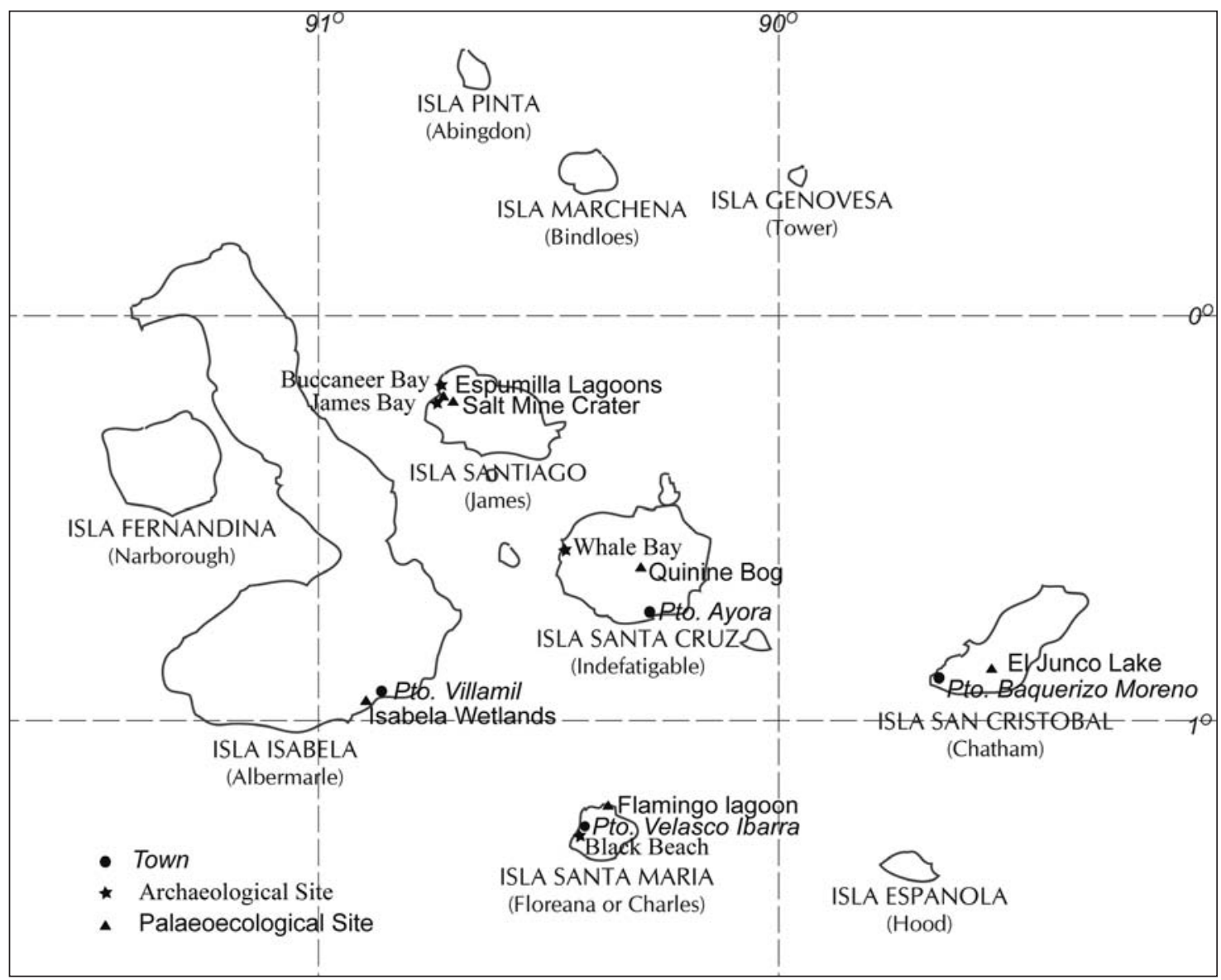

Figure 2. Map of the Galapagos Islands showing main towns, and the ANU archaeological and palaeoecological sites. Island names in brackets are the original 'English' names, not commonly used now except for 'Floreana Island' for Isla Santa Maria. 
No structures, monuments, middens, ancient agricultural features nor domestic-animal introductions were reported at the time, nor have any been found since. Archaeological evidence, then, comes in the form of surface and subsurface scatters of pottery and other artefacts, as well as palaeoecological information about how vegetation, insect populations and water quality have changed over time.

The ANU-led expedition to the Galapagos in 2005 was only the fourth international party to visit the Galapagos for archaeological excavations. The previous reported visits were the Norwegian Archaeological Expedition led by Thor Heyerdahl in 1953, the Walt Disney Galapagos Expedition led by J.C. Couffer and C. Hall in 1954 (Heyerdahl and Skjølsvold 1990), and a geology/archaeology field school organised by the Escuela Superior Politecnica del Litoral (ESPOL, Guayaquil) and led by Raul Maruri in 1963. Over the years, other scientists and interested non-archaeologists have deposited various finds in the small museum housed in the Charles Darwin Research Station, (Peurto Ayora, Isla Santa Cruz, Galapagos), and this material was available for analysis by our group.

Heyerdahl and Skjølsvold originally published their analysis of Galapagos archaeology in American Antiquity in 1956. A reprint with minor changes followed in 1990. Their primary conclusion was that some of the ceramics they discovered were of coastal Ecuadorian and Peruvian origin, and pre-dated European influence in the region. This conclusion was based on typological similarities between the Galapagos collection and pottery from mainland Ecuador and Peru, which was thought, in the 1950s, to be pre-Columbian (some has since been reclassified). At the time, there were mixed reviews of the work, with some authors finding the archaeological conclusions plausible (Bushnell 1957; Evans 1958), and others arguing that some of the identifications of Galapagos pottery were 'daring', and did not provide 'direct confirmation' of pre-Spanish visits to Galapagos (Ryden 1958). In 1967, Robert Suggs published a 'statistical re-analysis' of the Galapagos data (Suggs 1967), critiquing Heyerdahl's archaeological methods and conclusions, and summarising that 'the hypothesis of aboriginal visits to the Galapagos must be rejected', and 'historical, botanical and archaeological evidence strongly indicate that the aboriginal pottery was introduced by Europeans' (Suggs 1967).

A critical but supportive view was provided by Edward Lanning (1969), who did not agree with Heyerdahl's typological assessment, but rather identified the pottery as Ecuadorian, and dated from AD 1200 to AD 1400. Since then, several authors have been critical of Heyerdahl's Pacific colonisation theories and, in passing, his Galapagos work, but no other publications have dealt specifically with the Galapagos ceramics, and no-one has attempted to re-excavate there.

Several palaeoecological research projects have been conducted in and around the Galapagos Islands, although none with the explicit aim of searching for signs of human activity. Dunbar et al. (1994) used stable isotope ratios in uplifted corals from the west coast of Isabela to reconstruct annual sea surface temperature variability from AD 1587 to 1982 . The authors then analysed variance in the ENSO frequency band, which was usually about 4.6 years, but shifted to higher frequencies in the early to middle 1700s and the middle 1800s (Dunbar et al. 1994). Riedinger et al. (2002) also focused on El Nino activity, using the mineralogy and geochemistry of laminations preserved in a saline lake to identify different El Nino events and their approximate intensities. They conclude that over the past 1000 years, there have been 36 strong events and five moderate events, while in the 1000 years before that, there were only 14 strong events and 152 moderate events. Mid-Holocene El Nino frequencies were estimated to have been lower than those in the late Holocene. The low lake levels inferred for El Junco lake, San Cristobal, in the mid-Holocene support this finding, as well as the idea that before $5000 \mathrm{BP}$, wetter conditions prevailed (Colinvaux 1972; Riedinger et al. 2002). 
Palynological analysis of sediments from El Junco lake revealed remarkable stability in the taxa represented in the pollen and spore records over the Holocene (Colinvaux and Schofield 1976a; Colinvaux and Schofield 1976b), but no special attention was paid to the period of human impact. Colinvaux and Schofield attribute changes in the amounts of some taxa in the past 400 radiocarbon years to cattle disturbance and forest clearance, but higher resolution records (both temporally and taxonomically) would probably be required to confirm human environmental impacts in the San Cristobal highlands.

Fieldwork for the ANU project, led by Atholl Anderson and Simon Haberle, took place in 2005. Coring and sampling for later palaeoecological analysis was carried out over two seasons, 2005 and 2006, with some sampling equipment left in place for the intervening year. Localities investigated and referred to below are marked on Figure 2. Whale Bay, James Bay, Black Beach and Buccaneer Bay archaeological sites were re-investigated following earlier maps and descriptions (Heyerdahl and Skjølsvold 1990). Other sites, including many suitable landing sites on Santa Cruz, Santiago, San Cristobal and Isabela Islands were surveyed for the first time. Interviews were conducted with farmers, scientists and long-term residents of the archipelago about their knowledge of archaeological artefacts and clay and water sources.

About 1600 artefacts were found in excavations. About one third were ceramic fragments and the rest were pieces of metal, glass, charcoal, shell and bone. While the analysis of these materials is incomplete, the initial conjecture by Pacific and Ecuadorian archaeologists participating in this research was that the assemblages recovered date to the historical era (Anderson pers comm. 2007; Stothert 2007). The following research methodology was used to further examine this conclusion. A detailed description of our results will be published elsewhere.

\section{Archaeology}

a) Re-analysis of the sites. Heyerdahl and Skjølsvold's (1990) document has been criticised and almost certainly contains errors, some of which were the result of advice given by archaeologists from Peru and the United States, working to the best of their knowledge at the time (see Evans 1958; Heyerdahl and Skjølsvold 1990:32). Other errors may be methodological, analytical or logical (Suggs 1967). One of the suggestions is that analysis of the collections (and possibly the collecting procedures themselves) was biased towards material which was not obviously modern (i.e. glass, plastics, metal), and that therefore the resulting comparisons with mainland assemblages were flawed (Suggs 1967). The re-analysis conducted in 2005 has rectified some of these problems; both sampling and assemblage comparisons have included all artefacts, regardless of likely origin.

Heyerdahl reports no stratigraphic separation between European and Amerindian sherds at any of the sites, and it is difficult to tell whether this is a result of the sherds being 'mixed naturally as they were deposited' (Suggs 1967), or whether a combination of thin soils and post-depositional disturbance by people, animals and rainfall events would be enough to remove the stratigraphy, as Heyerdahl suggests. The ANU re-analysis has also found no clear stratigraphic delineation between modern material and ceramics that are potentially pre-European, even at the new sites. Mixing of different-aged artefacts is a common situation in archaeological sites, especially where natural or cultural postdepositional processes have been involved (Feathers 2003). This seems particularly likely in areas with periodic heavy rainfall, such as the Galapagos. A first-hand account by Heyerdahl and Skolsvold (1990) mentions that after heavy rain, pottery was being washed out of the soil at Black Beach (Heyerdahl and Skjølsvold 1990:31), and in several other locations they 
believed sherds had been relocated by the movement of water, in some cases into the sea (e.g. Heyerdahl and Skjølsvold 1990:26, 25).

b) Re-analysis of the types of pottery in all the available collections. Some of the pottery classifications used by Heyerdahl are no longer used by South American archaeologists (Stothert 2007), and the periods of production of some types have been redefined to include the early colonial period. In the light of this new understanding of South American indigenous ceramics, the 2005 collections, as well as material collected by Heyerdahl and Skjølsvold (1990) and the later Galapagos archaeological expeditions, are being re-analysed. Modern statistical techniques for comparing assemblages will allow a more accurate evaluation of the similarities between Galapagos and mainland assemblages.

c) Chemical characterisation of pottery. Ceramics can be chemically characterised to allow analysts to determine whether two pottery assemblages could be sourced from similar clay. Variability in pottery designs (morphology and decoration) is compared with chemical data, and an extra set of relationships may emerge (Summerhayes 2000). This allows assessment of the similarity of pottery over space and time. The clay matrices and the mineral inclusions (known as 'non-plastics') of selected Galapagos samples have been compared with typical coastal Ecuadorian pottery sherds, and groups of pottery have been classified based on chemical similarities.

d) Direct dating of archaeological materials. Radiocarbon dating of pieces of charcoal discovered in hearths at four of the archaeological sites has been used to determine the likely age of the fireplaces. These could be ancient hearths used by pre-European voyagers, remnants of the whaling and sealing era, or more recent features. Charcoal fragments were identified to species where possible and dated at the Oxford radiocarbon laboratory.

Pottery fragments can also be directly dated using Optically Stimulated Luminescence (OSL). OSL is a technique that measures the amount of luminescence emitted by a sample after it has been stimulated with light. The amount of luminescence emitted is proportional to the amount of time passed since the sample was last exposed to light (or heat of about 400C). Calculations for working out the age (or time since last exposure) must take into account the natural radioactivity of the sample and its surroundings, since the luminescence signal is building up as a result of exposure to ionising radiation (Aitken 1998). Fragments of pottery from Galapagos and mainland Ecuador have been analysed using this technique at the Australian National University.

Each of the techniques for analysing the pottery is potentially able to answer part of the question of the origin (place and time) of the Galapagos ceramics. However, there is likely to be some continuing element of ambiguity, since it was apparently quite common practice in colonial times for Europeans visiting mainland South America to use locally produced pottery for storage of foods during transit, and also to souvenir (via theft or purchase) desirable ceramics and artefacts (Suggs 1967, and reference to a German work therein). Visits to the Galapagos were commonly made by ships leaving South America en route to Europe to obtain water, tortoise meat, salt and shelter, so some pre-1535 pottery could have been transported from the mainland, then abandoned in Galapagos. For this reason, multiple lines of evidence will be necessary to construct an argument about the origins of the Galapagos pottery assemblages. An argument will be more convincing if it is corroborated by radiocarbon dates from fireplaces, and palaeoecological information about anthropogenic environmental changes pre-dating European arrival. 


\section{Palaeoecology}

A combination of palaeoecology and archaeology in the Juan Fernandez Islands showed it was unlikely there had been human activity in the islands before Europeans arrived (Anderson et al. 2002; Haberle 2003). In the Galapagos Islands, a similar approach is being used, with palaeoecological techniques selected to:

- Look for the pollen and macrofossils of a variety of plant taxa which may (or may not) have been introduced by people;

- Look for other evidence of ecological change perpetuated by humans (e.g. soil erosion, charcoal from anthropogenic burning, alteration of the native vegetation composition, insect introductions);

- Accurately determine the timing of the above changes, if present;

- Consider the impacts the regional effects of climate variability may have had on the travel strategies of the original human occupants of the Pacific.

The sites chosen for the ANU project were first recognised as potential palaeoecological archives by Paul Colinvaux during exploratory fieldwork in the Galapagos in the 1960s. He briefly described the limnology and geomorphology of many of the crater lakes, coastal lagoons and bogs (Colinvaux 1968; Colinvaux 1969). As discussed earlier, relatively little palaeoecological research has been conducted in the Galapagos, and so almost all the sites chosen had never been cored before. The sites were selected on the basis of their proximity to the archaeological locations. Sediment cores were collected from five sites in 2005: Quinine Bog, Flamingo Lagoon, Isabela Wetlands, Salt Mine Crater and Espumilla Lagoon 1 (Figure 2).

Each site will be subject to a range of sedimentological and biotic proxy analysis, with particular focus on the past 1000 years. These sedimentological methods include: (i) Grey-scale analysis (Petterson et al. 1999) which records frequency of colour changes related to sediment type through the cores; (ii) Magnetic susceptibility which determines the concentration and composition of magnetic minerals in a sample (Nowaczyk 2001; Zolitschka et al. 2001) and can be associated with climatic variability and/or anthropogenic disturbance, including fires and forest clearance (Dearing et al. 1981; Dearing and Flower 1982; Nowaczyk 2001; Whitlock and Larsen 2001); (iii) Loss on ignition (LOI, Dean 1974) to estimate the organic and carbonate contents of sediment; (iv) X-ray fluorescence to quantify variations in 30 elements at $0.2 \mathrm{~mm}$ intervals (Croudace et al. 2006).

A range of biotic proxies are also being used, including: (i) Palynology and micro-charcoal analysis to reconstruct vegetation succession over the late Holocene and yield specific information about human activities in relation to the flora; (ii) Testate amoebae preserved in Sphagnum bogs, which are sensitive to changes in hydrology, as palaeo-precipitation indicators; (iii) Diatom analysis to reconstruct water quality and depth changes through time.

Of these three biotic indicators, palynology is most likely to yield significant information on human activity, due to the potential presence of cultivars associated with the Polynesian expansion into the east Pacific, such as sweet potato (Ipomea batatas), banana (Musa sp.), coconut (Cocos nucifera), taro (Colocasia esculenta), flax (Phormium tenax), Pacific Island cabbage tree (Cordyline fruticosa) and Hibiscus (Macphail et al. 2001; Horrocks and Lawlor 2006). Evidence of common South American cultivars, such as maize (Zea mays), chilli (Capsicum sp.), potato (Solanum sp.) and cotton (Gossypium sp.), at any of the sites before AD 1535 could also be strong evidence for Amerindians reaching Galapagos shores (Stephens 1963; Perry et al. 2007). 
Table 1. Origins of Galapagos taxa listed as 'Questionable Natives' that have a non-American origin.

\begin{tabular}{|c|c|c|c|}
\hline Family & Genus & Species & Origins and Distribution after the PIER database (US Forest Service website) \\
\hline Convolvulaceae & Stictocardia & tiliifolia & $\begin{array}{l}\text { 'Now circumtropical, apparently originally from Africa or Asia, cultivated widely and } \\
\text { introduced into the New World' (Smith 1991). }\end{array}$ \\
\hline Cyperaceae & Eleocharis & geniculata & 'Widespread in tropical and subtropical regions of both hemispheres' (Smith 1979). \\
\hline Fabaceae & Galactia & tennuiflora & Africa, tropical Asia, China, Taiwan, Australia (GRIN). \\
\hline Poaceae & Digitaria & ciliaris & Tropical Asia \\
\hline Poaceae & Eragrostis & cilianensis & $\begin{array}{l}\text { 'Tropical and warm temperate regions of the Old World, now naturalised in the New } \\
\text { World' (Wagner et al. 1999). }\end{array}$ \\
\hline Poaceae & Oplismenus & compositus & $\begin{array}{l}\text { 'Tropical regions of the old and new worlds.' (Smith 1979). Native or an early introduction } \\
\text { to many Pacific islands. Considered an early introduction to Fiji (Smith 1979) and Niue. } \\
\text { Fosberg et al. (1987) list it as native to Micronesia. }\end{array}$ \\
\hline Poaceae & Oplismenus & setarius & Pantropical. Fosberg et al. (1987) lists as native in Micronesia. (Under 0. hirtellus) \\
\hline Portulacaceae & Portulaca & oleracea & $\begin{array}{l}\text { 'Nearly cosmopolitan, although presumably native to the Old World' (Wagner et al. } \\
\text { 1999). 'Probably an early European introduction to Polynesia' (Whistler 1988). }\end{array}$ \\
\hline Solanaceae & Solanum & americanum & $\begin{array}{l}\text { Most probably an early introduction throughout the Pacific area. 'Common in disturbed } \\
\text { areas from southern Georgia to Florida, west to California, and south through Mexico to } \\
\text { Central and South America (Schilling 1981); additionally it now occurs as an abundant } \\
\text { weed throughout much of the Paleotropics.' (Smith 1991). 'Aboriginally introduced, or } \\
\text { possibly native, to Polynesia' (Whistler 1988). }\end{array}$ \\
\hline Zygophyllaceae & Tribulus & terrestris & $\begin{array}{l}\text { Mediterranean region, now widely naturalised in warm temperate and tropical regions } \\
\text { (Holm et al. 1977) }\end{array}$ \\
\hline
\end{tabular}

Of the plants listed above, only coconut, hibiscus and cotton are naturalised, but most of the others are now cultivated in the Galapagos. This should allow palynologists to readily identify (and in some cases confirm) the timing of the introductions, but unfortunately, many cultivars are rarely found in the pollen record, due to poor preservation, uncertain identification, cultivation methods which prevent flowering, or the absence of wind pollination (Haberle 1994; Maloney 1994). Another category of plants to be investigated is the 62 species growing in the Galapagos today listed by local botanists as 'questionable natives'. Palaeoecology can potentially provide important information about the timing of the introductions of these plants, allowing ecologists to design appropriate management strategies (Willis et al. 2007). In fact, van Leeuwen et al. (2007) have shown that about 20 of the Galapagos' 'questionable natives' can be differentiated from similar 'native' taxa on the basis of their pollen. Of these, they have already reclassified the status of six taxa (van Leeuwen et al. 2007) by analysing bog deposits dating from before European discovery of the archipelago. Questionable natives listed in Table 1 have an Asia-Pacific origin, unlike much of the Galapagos flora, which originates in South America. Work continues to determine whether their introduction pre-dated AD 1535. Evidence that these taxa were growing in the Galapagos before European influence would constitute a strong line of evidence for accidental or deliberate landfall in the Galapagos by a Polynesian vessel.

The case study below demonstrates the use of these simple but important methods on a core from one of the Espumilla coastal lagoons on the island of Santiago. 


\section{Espumilla Lagoon case study}

\section{Site description and methods}

Espumilla Lagoon 1 is a dry lake bed just north of the James Bay archaeological site on the northwest coast of Santiago Island (Figure 2; GPS coordinates: $0.20182^{\circ} \mathrm{S}, 90.82677^{\circ} \mathrm{W}, 2 \mathrm{~m}$ asl). It is the largest of three coastal lagoons separated from the ocean by a $3 \mathrm{~m}$ high mangrovecovered sand-dune barrier. Espumilla Lagoon was cored with a hand-operated piston corer (5 $\mathrm{cm}$ diameter) in July 2005. Duplicate cores (SAE1 and SAE2) with overlapping core sections were collected, wrapped in plastic, stored in PVC tubes and transported to the ANU. Each section was subsequently split lengthways, with half stored for archival purposes, and the other half logged, photographed and used for analyses.

Photographs of SAE1 and SAE2 were analysed with Scion Image, a program which can provide line plots of the grey-scale variation in images of the core. Magnetic susceptibility was measured using a $2 \mathrm{~cm}$ wide Bartington Magnetic Susceptibility Loop (Dearing 1999) with contiguous $1 \mathrm{~cm}$ sample spacing, and results were corrected for machine drift. The LOI analysis was conducted by adhering to the recommendations made by Heiri et al. (2001). Standardised sample sizes $(1 \mathrm{cc})$ of dry material were weighed into ceramic 'boats' and oxidised in a furnace at 550C for four hours. Organic material was combusted at this stage, and after samples were cooled, and reweighed, the amount of lost organic material was calculated. Samples were then returned to the furnace, this time at $950 \mathrm{C}$ for two hours, and then reweighed to determine the amount of carbonate lost. Results are shown as percentages of original dry weight (Figure 3).

Twenty-two radiocarbon dates from SAE1 and SAE2 were submitted to the Australian Nuclear Science and Technology Organisation (ANSTO). 'Bulk' sediment was used for all but three samples, which were pollen extractions paired with bulk samples designed to test whether pollen extractions returned superior results. Given the similarity in the calibrated ranges between pollen extractions and bulk sediments, the rest of the AMS dates were obtained on small samples of bulk sediment. All samples were pre-treated using the acid-alkali-acid method following standard procedures (ANSTO 2008). Radiocarbon ages were calibrated with Calib (Stuiver and Reimer 1993), using the 2004 southern hemisphere calibration curve (McCormac et al. 2004).

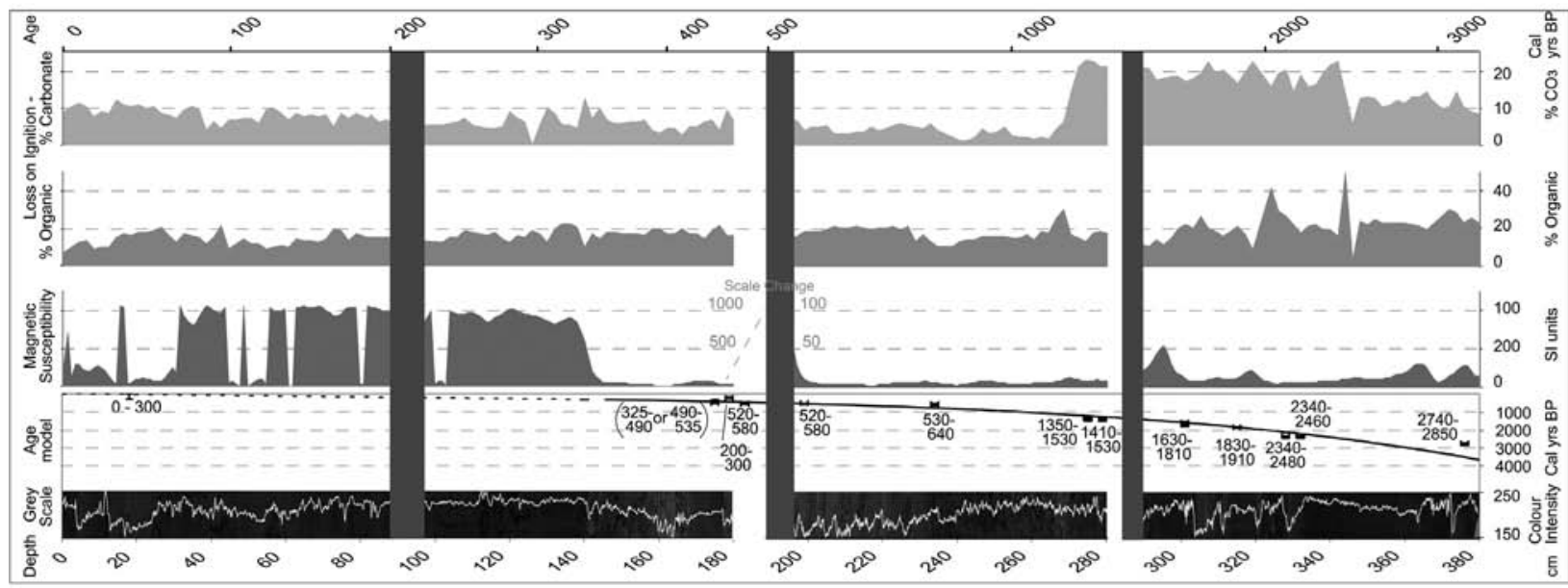

Figure 3. Results for Espumilla Lagoon 1 cores 1 and 2. From bottom to top, results shown are: Depth (cm); Grey-scale measure of colour intensity overlain on photographs of the core; Radiocarbon dates in cal. BP and age model; Magnetic susceptibility (SI units; note scale change at $2 \mathrm{~m}$ ); and Loss On Ignition (\%Organic and \% $\mathrm{CO}_{3}$ ). Blacked-out sections conceal areas of contamination, which occurred as a result of coring. 
The overlapping sections of SAE1 and SAE2 were correlated using sedimentological parameters such as colour, texture and magnetic susceptibility. SAE1 is pictured in Figure 3 and will be described here. Grey-scale overlay plots in Figure 3 help to highlight bands of pale and dark colour intensity. The top $140 \mathrm{~cm}$ of the core is composed of dark red-brown silt with bands of silty clay, silty sand, firm pale-brown clay and course sandy or gravelly layers throughout. Some sections fine upwards. Between $175 \mathrm{~cm}$ and $140 \mathrm{~cm}$, two distinct sediment types alternate. Two bands of distinctive pale-grey clay containing sand and gravel-sized clear gypsum crystals alternate smoothly with layers of the same dark reddish sediment as above. A sharp boundary marks the transition at $175 \mathrm{~cm}$. From $235 \mathrm{~cm}$ to $175 \mathrm{~cm}$, there is pale-grey crystalline sand with occasional dark coarse grain bands, or pale clay-rich bands $(<1 \mathrm{~cm})$. The sediment from $272 \mathrm{~cm}$ to $235 \mathrm{~cm}$ consists of much larger gypsum crystals in the same grey silty or clay matrix. The gypsum crystals do not appear to be aligned, although they were clearly disturbed during the coring process due to the large size of the crystals (some up to $5 \mathrm{~cm}$, but commonly $2-3 \mathrm{~cm}$ long). A fairly smooth transition between $277 \mathrm{~cm}$ and $272 \mathrm{~cm}$ delineates the lowest core section. Dominated by light green-grey to dark-grey, slightly sandy silt, this section has five layers which appear on the grey-scale graph as paler bands, and are actually very fine (1-3 $\mathrm{mm})$ pink, green, black and white (calcareous) laminations. Especially in the laminated sections, but elsewhere as well, hard white (probably calcareous) sand grains are distributed throughout the silt.

Statistical analysis of geochemical data from this core (Flett et al. 2007) confirms there are four distinct stratigraphic layers: Unit 1 from the base to about $280 \mathrm{~cm}$; Unit 2 from $280 \mathrm{~cm}$ to $175 \mathrm{~cm}$; Unit 3, a transitional layer, from $175 \mathrm{~cm}$ to $140 \mathrm{~cm}$; and Unit 1 above $140 \mathrm{~cm}$.

Distinctive sediment properties characterise the four units. Unit 1 has mostly low magnetic susceptibility, with some slightly elevated readings corresponding to non-laminated sections with slightly lower organic percentages than the rest of the unit. X-ray analysis reveals also that these elevated magnetic susceptibility readings correspond to denser material (Flett et al. 2007). Carbonate percentages in Unit 1 are higher than in the rest of the core, mostly between 10 percent and 20 percent. The organic component of the sediment is mostly above 20 percent for Unit 1 . Unit 2 has consistently low magnetic susceptibility, a fairly low organic content, of about 18-20 percent, and a low percentage of carbonate, at about five percent. Unit 3 is very similar to Unit 2, except for the section between $175 \mathrm{~cm}$ and $165 \mathrm{~cm}$, which is more similar to Unit 4. The sediment appearance and texture is the same as much of Unit 4, and the magnetic susceptibility is higher than in the older sediment, at about 100 units. Unit 4 is characterised by an extremely unusual magnetic susceptibility profile. Very high readings of up to 1000 units are reached, but between these high-susceptibility sediment blocks are layers with much lower magnetic susceptibility. Organic content varies between 10 percent and 20 percent over this unit, with carbonate content mostly around eight percent, but increasing towards the top of the core. A rough correlation between paler-coloured sediments and lower values of magnetic susceptibility can be noticed, and there are also several layers in which coarser-grained material tends to be related to the high-susceptibility layers.

The age model for the lower part of SAEL1 and SAE2 is based on a log curve trend line, fitted through 12 of the AMS radiocarbon dates (Figure 3). Although 22 samples were submitted for dating (Table 2), six samples were modern, and three were paired samples from the same depths as those used in the age model. The paired samples were left out of the diagram to reduce confusion, and the six modern samples were not used in this particular age model, although they are being calibrated with the 'bomb spike' calibration curve and will be discussed in a separate publication. Lead-210 analysis was attempted using the Po-Ra method and alpha spectrometry (Appleby and Oldfield 1992), but counts of the Ra and Po isotopes were too low and inconsistent to be used. 
Table 2. Conventional radiocarbon ages for 22 Espumilla Lagoon samples submitted to ANSTO.

\begin{tabular}{|c|c|c|c|c|c|}
\hline ANSTO code & Sample type & Submitter ID & ${ }^{13} \mathrm{C}$ & $\%$ Modern & CRA \\
\hline $0 Z 1495$ & Lake sediment & SAE-2-20-B & -23.1 & 97.82 & $180 \pm 70$ \\
\hline 0ZI481 & Pollen extraction & SAE-2-20-P & -28 & 110.02 & Modern \\
\hline 0ZJ651 & Lake sediment & SAE-1-49 & -26.1 & 103.24 & Modern \\
\hline $0 Z 1494$ & Lake sediment & SAE-2-90 & -24.8 & 110.69 & Modern \\
\hline 0ZJ652 & Lake sediment & SAE-2-105 & & 101.04 & Modern \\
\hline 0ZJ653 & Lake sediment & SAE-1-141 & -25.5 & 104.17 & Modern \\
\hline 0ZJ654 & Lake sediment & SAE-1-144 & -23.0 & 148.7 & Modern \\
\hline $0 Z 1496$ & Lake sediment & SAE-2-178-B & -25.4 & 94 & $495 \pm 40$ \\
\hline 0ZI482 & Pollen extraction & SAE-2-178-P & -25.6 & 95.35 & $385 \pm 45$ \\
\hline 0ZJ663 & Lake sediment & SAE-2-181 & -16.9 & 96.74 & $265 \pm 50$ \\
\hline 0ZJ655 & Lake sediment & SAE-2-186 & -19.2 & 92.92 & $590 \pm 50$ \\
\hline 0ZJ656 & Lake sediment & SAE-2-190 & -17.5 & 93.03 & $580 \pm 45$ \\
\hline 0ZJ657 & Lake sediment & SAE-2-225 & -16.3 & 93.11 & $570 \pm 60$ \\
\hline 0ZJ659 & Lake sediment & SAE-2-266 & -17.0 & 82.1 & $1580 \pm 60$ \\
\hline 0ZI483 & Pollen extraction & SAE-2-281-P & -14.7 & 79.88 & $1800 \pm 60$ \\
\hline $0 Z 1472$ & Lake sediment & SAE-2-281-B & -18.9 & 80.84 & $1710 \pm 50$ \\
\hline 0Z1804 & Lake sediment & SAE-2-295 & -19.9 & 78.67 & $1930 \pm 40$ \\
\hline $0 Z \mathrm{ZJ} 660$ & Lake sediment & SAE-2-305 & -16.5 & 74.42 & $2370 \pm 60$ \\
\hline 0ZJ661 & Lake sediment & SAE-1-332 & -14.6 & 74.58 & $2355 \pm 50$ \\
\hline 0ZJ662 & Lake sediment & SAE-2-363 & -18.5 & 71.69 & $2670 \pm 70$ \\
\hline $0 Z 1473$ & Lake sediment & SAE-2-382 & -15.9 & 64.93 & $3470 \pm 50$ \\
\hline
\end{tabular}

The radiocarbon results below the uppermost $175 \mathrm{~cm}$ fit reasonably well $\left(\mathrm{R}^{2}=0.96\right)$ to a log trend line, with equation $y=95.458 \operatorname{Ln}(x)-403.45$. For the uppermost samples, five out of the six results are modern, and most of these samples were taken from the dark red-brown sediment of the upper $140 \mathrm{~cm}$. About $180 \mathrm{~cm}$ of sediment in the top part of the core accumulated in -500 years, which is a dramatic change in sedimentation rate compared with the lower part of the core. The reasons for the lack of meaningful radiocarbon dates in the top half of the core warrant careful consideration.

\section{Discussion}

A basic sedimentological assessment can provide information about the changing palaeoenvironmental setting of the Espumilla basin. Although we cannot date when sediment started accumulating in lagoons behind Espumilla beach, many similar back-barrier lagoons formed during the late Holocene as a result of relative sea-level stability after post-glacial sea-level rise. In Unit 1, the lagoon sediments indicate relatively deep water, probably brackish or marineinfluenced. In Bainbridge crater, Galapagos, periods of stratification in a generally deep water column, caused by an influx of fresh water during an El Nino event are suggested to be the cause of laminations (Riedinger et al. 2002). If the same situation caused the laminations in Unit 1 
of the Espumilla core, then there were five periods of stratified conditions indicating extreme climatic events between c. $1450 \mathrm{cal}$. BP and $2800 \mathrm{cal}$. BP. Unit 2 is an evaporite sequence indicating a period in which the water was a shallow concentrated brine, with relatively stable chemistry. This allowed gypsum precipitation after the lake's previous calcareous phase, leading to the reduced carbonate content of the sediment. Low magnetic susceptibility values are often attributed to organic or autochthonous sediment, with high values signifying terrestrial erosion and run-off (Dearing 1999; Nowaczyk 2001). About 500 years ago, a transitional period began. The striking rise in magnetic susceptibility, along with other geochemical factors, are discussed in Flett et al. (2007), and indicate that terrestrial material began to dominate. The sedimentation rate also dramatically increased, with around the same amount of sediment accumulating in the past 500 years as in the previous 2500 years. It is unclear whether these changes were due to geomorphologic, climatic or anthropogenic factors.

The lake basin itself could have filled with sediment during the evaporite phase, resulting in a natural end to the standing-lake phase. This does not fully explain the change in sediment type, however, as the red-brown silt with high magnetic susceptibility is not evident in the earlier sediments. The magnetic susceptibility signal in Unit 4 is particularly interesting, since it allows us to speculate that the terrestrial material is not arriving in the lake constantly (e.g. via a permanent turbid stream), but in bursts. This is consistent with rainfall patterns in the Galapagos lowlands, where it is generally very dry, except during extreme rainfall events associated with El Nino periods (Snell and Rea 1999). Unfortunately, the lack of chronological certainty for the past c. 500 years frustrates efforts to attribute each influx of sediment to a particular El Nino event. It should be noted, however, that there are eight high magnetic susceptibility levels in the past 500 years, and eight extreme events reported in Bainbridge crater (Riedinger et al. 2002).

Instead of intensification of the frequency and/or severity of El Nino events, there are two alternative explanations for the change in sediment type. One concerns the recent volcanism in James Bay, which is the large bay on the northwest coast of Santiago encompassing the Espumilla lagoons and the James Bay and Buccaneer Bay archaeological sites. In 1835, when Charles Darwin explored the region, he noticed pieces of pottery stuck in a recent lava flow in James Bay, one of which had the date of 1684 stamped on it (Darwin 2001). The region has been volcanically active, then, during the past 400 years, and it is possible that the shape of the catchment was changed by this activity, or that the recent sediment is different from earlier material because it is, in fact, freshly eroded lava. More geochemical analysis is required to test this hypothesis.

The third possible explanation for the change in sediment type is that this is roughly the time Europeans arrived. Burning of vegetation and the introduction of goats and pigs are known to have dramatically destabilised sediment in other island environments, and this could also have occurred here. Estimates for when goats and pigs were introduced are in the early 1800s (Cruz et al. 2005; Woram 2005), which is slightly inconsistent with the current (preliminary) age model, but could certainly be explained by considering the significance of the inconsistent dates in Unit 3, which could make the transition as late as 300 years ago. Charcoal and pollen analysis, as well as further attempts to improve the chronology of Units 3 and 4, are underway.

\section{Future directions}

One of the most significant results of the initial archaeological and palaeoecological research underway in the Galapagos Islands is the clear indication that there have been massive changes in sediment mobilisation within the past 1000 years, with a major increase in catchment erosion in the coastal areas most likely dating to between 500 and 300 years ago. While we have 
outlined a number of interpretations relating this event to anthropogenic and natural processes, the final identification of the cause must depend on multi-proxy data from archaeological and palaeoecological archives. Both these lines of evidence are pointing towards anthropogenic impacts being restricted to the post-European discovery period (post AD 1535).

This still leaves one of the outstanding uncertainties of Pacific prehistory, which is the extent to which it has an Amerindian component. There is no doubt there has been some such influence, as outlined above, though the question remains as to whether this represents a single event of Amerindian or Polynesian voyaging, perhaps accidental, or is indicative of more frequent, possibly systematic seafaring behaviour in the far-eastern Pacific. While our investigations in the far-eastern Pacific Islands, at the moment, do not favour any of the hypotheses, there is a growing body of evidence to suggest the far-eastern islands did not play a 'stepping stone' role in the interaction between Amerindians or Polynesians in prehistory.

Our focus on issues of island colonisation in the remote eastern Pacific Ocean has provided the opportunity to substantially advance the knowledge base of the discipline in several areas. Firstly, the tension that exists between archaeological and palaeoecological evidence for island colonisation stems from our lack of understanding about the nature of human interaction with small island landscapes, and the difficulty of separating natural processes from human-induced environmental change. In the far-eastern Pacific Islands we have been able to overcome this problem in interpreting records of environmental change by: (1) deriving proxy data from multiple sites across a region of contrasting human occupation history in order to distinguish the regional climate trends from local human activity; and (2) deriving proxy data from areas with no, or a very short and well-defined, history of human occupation.

Finally, the islands of the far-eastern Pacific Ocean have long been considered pristine and unspoilt landscapes, and as such, have represented a unique opportunity to study the evolution and dynamics of biota in the absence of human interference (Larson 2002). However, the islands are also extremely sensitive to anthropogenic impact due to their generally small size, isolation, vulnerability to pest and weed invasion, and low biodiversity relative to continental landmasses. By applying palaeoecological and archaeological analysis at fine spatial and temporal resolutions, we will have the opportunity to define the period of human impact and assess the rate and extent of anthropogenic changes.

\section{Acknowledgments}

The research discussed in this paper is funded by the Australian Research Council (under the Stepping Stones or Barriers ARC Discovery project) and an APA to Iona Flett. Additional funding has also been provided by the Australian Institute for Nuclear Science and Engineering, which has supported research conducted at ANSTO under its Post-Graduate Research Award Scheme. The authors are grateful to Dr Henk Heijnis and Dr Geraldine Jacobsen who have provided advice on chronological techniques mentioned in this paper. We would also like to thank staff at the Charles Darwin Research Station in the Galapagos who assisted with fieldwork and permit requirements. Most importantly, we need to acknowledge the contribution of Atholl Anderson to this project, in which he is an active leader. His influence in all stages of the research, from developing the application to publishing the results, has been invaluable, and we look forward to much fruitful collaboration in the future. 


\section{References}

Aitken, M.J. 1998. An Introduction to Optical Dating. Oxford: Oxford University Press.

Allen, M.S. 2006. New Ideas about Late Holocene Climate Variability in the Central Pacific. Current Anthropology 47(3):521-535.

Anderson, A. 1991. The chronology of colonization in New Zealand. Antiquity 65:767-795.

Anderson, A. 2003. Initial human dispersal in remote Oceania: pattern and explanation. In C. Sand (ed), Pacific archaeology: assessments and prospects, pp. 71-84. Noumea: Service des Musees et du Patrimoine.

Anderson, A. 2005. Subpolar settlement in South Polynesia. Antiquity 79:791-800.

Anderson, A. 2006. Polynesian seafaring and American horizons: A response to Jones and Klar. American Antiquity 71(4):759-763

Anderson, A., J. Chappell, M. Gagan and R. Grove 2006. Prehistoric maritime migration in the Pacific islands: an hypothesis of ENSO forcing. The Holocene 16(1):1-6.

Anderson, A., S. Haberle, G. Rojas, A. Seelenfreund, I. Smith and T. Worthy 2002. An archaeological exploration of Robinson Crusoe Island, Juan Fernandez Archipelago, Chile. In S. Bedford, C. Sand and D. Burley (eds.), Fifty years in the field, essays in honour and celebration of Richard Shutler Jr's archaeological career, pp. 239-249. Auckland: New Zealand Archaeological Association.

ANSTO, 2008. Pretreatment of Organic Samples from Sediment, pp.1-8. Australian Nuclear Science and Technology Organisation, NSW.

Appleby, P.G. and F. Oldfield 1992. Application of Lead-210 to Sedimentation Studies, In M. Ivanovich and R.S. Harmon (eds), Uranium-series Disequilibrum: Applications to Earth, Marine and Environmental Studies, pp. 731-778. New York: Oxford University Press.

Ballard, C. 2005. Still good to think with: the sweet potato in Oceania. In C. Ballard, P. Brown, R.M. Bourke and T. Harwood (eds), The Sweet Potato in Oceania: A reappraisal, pp. 1-13. Sydney: The University of Sydney and University of Pittsburgh.

Bellwood, P.S. 1997. Prehistory of the Indo-Malaysian Archipelago. Honolulu, Hawaii: University of Hawai'i Press.

Bruhns, K.O. 1994. Ancient South America. Cambridge: Cambridge University Press.

Bushnell, G.H.S. 1957. Review: 200. Reviewed Work: Archaeological Evidence of Pre-Spanish Visits to the Galapagos Islands by Thor Heyerdahl; Arne Skjolsvold. Man 57:156-157.

Clarke, A.C., M.K. Burtenshaw, P.A. McLenachan, D.L. Erickson and D. Penny 2006. Reconstructing the Origins and Dispersal of the Polynesian Bottle Gourd (Lagenaria siceraria). Molecular Biology and Evolution 23(5):893-900.

Colinvaux, P.A. 1968. Reconnaissance and Chemistry of the Lakes and Bogs of the Galapagos Islands. Nature 219:590-594.

Colinvaux, P.A. 1969. Paleolimnological Investigations in the Galapagos Archipelago. Mitt. Interntat. Verein. Limnology 17:126-130.

Colinvaux, P.A. 1972. Climate and the Galapagos Islands. Nature 240:17-20.

Colinvaux, P.A. and E.K. Schofield 1976a. Historical Ecology in the Galapagos Islands I. A Holocene Pollen Record from El Junco Lake, Isla San Cristobal. Journal of Ecology 64:989-1012.

Colinvaux, P.A. and E.K. Schofield 1976b. Historical Ecology in the Galapagos Islands II. A Holocene Spore Record from El Junco Lake, Isla San Cristobal. Journal of Ecology 64:1013-1030.

Croudace, I., A. Rigby and R.G. Rothwell 2006. ITRAX: description and evaluation of a new multifunction X-ray core scanner. Geological Society, London, Special Publications 267:51-63.

Cruz, F., C. Josh Donlan, K. Campbell and V. Carrion 2005. Conservation action in the Galapagos: feral pig (Sus scrofa) eradication from Santiago Island. Biological Conservation 121(3):473-478.

Darwin, C. 2001. Charles Darwin's Beagle Diary. Cambridge: Cambridge University Press.

Dean, W.E. 1974. Determination of carbonate and organic matter in calcareous sediments and sedimentary rocks by loss on ignition: comparison with other methods. Journal of Sedimentary Petrology 44:242-248. 
Dearing, J. 1999. Environmental Magnetic Susceptibility. Using the Bartington MS2 system. Kenilworth, England: Chi Publishing.

Dearing, J.A., J.K. Elner and C.M. Happey-Wood 1981. Recent sediment flux and erosional processes in a Welsh upland lake-catchment based on magnetic susceptibility measurements. Quaternary Research 16(3):356-372.

Dearing, J.A. and R.J. Flower 1982. The Magnetic Susceptibility of Sedimenting Material Trapped in Lough Neagh, Northern Ireland, and its Erosional Significance. Limnology and Oceanography 27(5):969-975.

Dunbar, R.B., G.M. Wellington, M.W. Colgan and P.W. Glynn 1994. Eastern Pacific sea surface temperature since 1600 A.D. The D18O record of climate variability in Galapagos corals. Paleoceanography 9(2):291-315.

Evans, C. 1958. Comments on Ryden's Review of Heyerdahl and Skjolsvold. American Antiquity 24(2):189.

Feathers, J.K. 2003. Use of luminescence dating in archaeology. Measurement Science and Technology 14:1493-509.

Flett, I., S. Haberle and H. Lamb 2007. High resolution geochemical analysis of laminated coastal lagoon sediments from the Galapagos Islands, Ecuador (Poster), In N.R. Catto (ed.), XVII INQUA Congress, p. 151. Cairns: Quaternary International.

Fosberg, F.R. and Sachet, M.H. 1987. Flora of Maupiti, Society Islands. The Smithsonian Institution. Atoll Research Bulletin 294:1-70.

Gartelmann, K.D. 1986. Digging up Prehistory. The archaeology of Ecuador. Quito: Libri Mundi.

Geist, D. 1996. On the emergence and submergence of the Galapagos Islands. Noticias de Galapagos 56:5-8.

Genz, J. and T.L. Hunt 2003. El Nino/Southern Oscillations and Rapa Nui Prehistory. Rap Nui Journal 17:7-14.

Gongora, J, N. J. Rawlence, V. A. Mobegi, H. Jianlin, J. A. Alcalde, J. T. Matus, O. Hanotte, C. Moran, G. Larson, A. Cooper 2008. Abstract: Does the genetic analysis of Chilean archaeological chicken bones support Polynesian contact? In A.J. Barham (ed), Archaeological Science Conference, 4-6 Feb, 2008, p. 13. Canberra: ANU.

Green, R.C. 2005. Sweet potato transfers in Polynesian prehistory, In C. Ballard, P. Brown, R.M. Bourke and T. Harwood. (eds), The Sweet Potato in Oceania: A reappraisal, pp. 43-62. Sydney: The University of Sydney, University of Pittsburgh.

Gumbel, A. 2005. Paradise lost in Galapagos crisis The Canberra Times, Monday May 2, pp. 2-3. Canberra.

Haberle, S. 1994. Anthropogenic indicators in pollen diagrams: problems and prospects for late Quaternary palynology in New Guinea. In J.G. Hather (ed), Tropical Archaeobotany, pp.172-201. London: Routledge.

Haberle, S.G. 2003. Late quaternary vegetation dynamic and human impact on Alexander Selkirk Island, Chile. Journal of Biogeography 30:239-255.

Hather, J. and P.V. Kirch 1991. Prehistoric seet potato (Ipomoea batatas) from Mangaia Island, Central Polynesia. Antiquity 65:887-893.

Heiri, O., A.F. Lotter and G. Lemcke 2001. Loss on ignition as a method for estimating organic and carbonate content in sediments: reproducibility and comparibilty of results. Journal of Paleolimnology 25:101-110.

Heyerdahl, T. 1952. American Indians in the Pacific: The Theory behind the Kon-Tike Expedition. London: Allen and Unwin.

Heyerdahl, T. and A. Skjølsvold 1990. Archaeological Evidence of Pre-Spanish Visits to the Galapagos Islands. Oslo: Norwegian University Press.

Holton, G.E.L. 2004. Heyerdahl's Kon Tiki Theory and the Denial of the Indigenous Past. Anthropological Forum 14(2):163-181. 
Holm, L.G., Plucknett, D.L., Pancho, J.V. and Herberger, J.P. 1977. The world's worst weeds: distribution and biology. East-West Center: University Press of Hawaii.

Horrocks, M. and I. Lawlor 2006. Plant microfossil analysis of soils from Polynesian stonefields in South Auckland, New Zealand. Journal of Archaeological Science 33:200-217.

Hunt, T.L. and C.P. Lipo 2006. Late Colonization of Easter Island. Science 311:1603-1606.

Irwin, G., S. Bickler and P. Quirke 1990. Voyaging by canoe and computer: experiments in the settlement of the Pacific Ocean. Antiquity 64:34-50.

Kennet, D., T. Anderson, M. Prebble, E. Conte and J. Southon 2006. Prehistoric human impacts on Rapa, French Polynesia. Antiquity 80:340-354.

Lanning, E. P. 1969. South America As Source For Aspects of Polynesian Cultures. In R.C. Green and M. Kelly (eds), Studies on Oceanic Culture History, pp. 175-185. Honolulu, Hawaii: Bernice P. Bishop Museum.

Larson, E.J. 2002. Evolution's Workshop: God and Science on the Galapagos Islands. London: The Penguin Press.

Levinson, M., R. Ward and J. Webb 1973. The Settlement of Polynesia: A Computer Simulation. Minneapolis: University of Minnesota Press.

Macphail, M.K., F.S. Hope and A. Anderson 2001. Polynesian Plant Introductions in the Southwest Pacific: Initial Pollen Evidence from Norfolk Island, In A. Anderson and P. White (eds), The Prehistoric Archaeology of Norfolk Island, Southwest Pacific, pp. 123-134. Sydney: Australian Museum.

Maloney, B.K. 1994. The prospects and problems of using palynology to trace the origins of tropical agriculture: the case of Southeast Asia, In J.G. Hather (ed), Tropical Archaeobotany, pp. 139-171. London: Routledge.

Martinsson-Wallin, H. and S.J. Crockford 2001. Early Settlement of Rapa Nui (Easter Island). Asian Perspectives 40(2):244-278.

McCormac, F., A. Hogg, P. Blackwell, C. Buck, T. Higham and P. Reimer 2004. SHCal04 Southern Hemisphere Calibration 0-11.0 cal kyr BP. Radiocarbon 46:1087-1092.

Montenegro, A., C. Avis and A. Weaver 2007. Modelling the prehistoric arrival of the sweet potato in Polynesia. Journal of Archaeological Science, In Press, pp.1-13.

Nowaczyk, N.R. 2001. Logging of Magnetic Susceptibility, In W.M. Last and J.P. Smol Dordrecht (eds), Tracking Environmental Change Using Lake Sediments. Volume 1: Basin Analysis, Coring and Chronological Techniques, pp. 155-170. The Netherlands: Kluwer Academic Publishers.

Nunn, P.D. 2000. Environmental Catastrophe in the Pacific Islands around A.D. 1300. Geoarchaeology 15(7):715-740.

Nunn, P.D. 2003a. Nature-Society Interactions in the Pacific Islands. Geografiska Annaler 85 B(4):219-229.

Nunn, P.D. 2003b. Revising ideas about environmental determinism: Human-environment relations in the Pacific Islands. Asia Pacific Viewpoint 44(1):63-72.

Nunn, P.D. and J.M.R. Britton 2001. Human-Environment Relationships in the Pacific Islands around A.D. 1300. Environment and History 7:3-22.

Perry, L., R. Dickau, S. Zarillo, I. Holst, D.M. Peasall, D.R. Piperno, M.J. Berman, R.G. Cooke, K. Rademaker, A.J. Ranere, J.S. Raymond, D.H. Sandweiss, F. Scaramelli, K. Tarble and J.A. Zeidler 2007. Starch Fossils and the Domestication and Dispersal of Chili Peppers (Capsicum spp. L.) Americas Science 315:986-988.

Petterson, G., B.V. Odgaard and I. Renberg 1999. Image analysis as a method to quantify sediment components. Journal of Paleolimnology 22:443-455.

Piperno, D., C. Amdres and K. Stothert 2000. Phytoliths in Cucurbita and other neotropical Cucurbitaceae and their occurrence in early archaeological sites from the lowland American tropics. Journal of Archaeological Science 27:193-208. 
Ramirez, J.M. 1990/91. Transpacific Contact: The Mapuche Connection. Rapa Nui Journal 4(4):53-55.

Riedinger, M.A., M. Steinitz-Kannan, W.M. Last and M. Brenner 2002. A $-610014 \mathrm{C}$ yr record of El Nino activity from the Galapagos Islands. Journal of Paleolimnology 27:1-7.

Ryden, S. 1958. Review of Arcaheological Evidence of Pre-Spanish Visits to the Galapagos Islands by Thor Hyerdahl; Arne Skjolsvold. American Antiquity 24(1):88-89.

Smith, Albert C. 1979. Flora Vitiensis nova: a new flora of Fiji. National Tropical Botanical Garden, Lawai, Kauai, Hawaii. Volume 1.

Smith, Albert C. 1991. Flora Vitiensis nova: a new flora of Fiji. National Tropical Botanical Garden, Lawai, Kauai, Hawaii. Volume 5.

Snell, H. and S. Rea 1999. The 1997-98 El Nino in Galapagos: Can 34 years of data estimate 120 years of pattern? Noticias de Galapagos p.60.

Stephens, S.G. 1963. Polynesian Cottons. Annals of the Missouri Botanical Garden 50(1/4):1-22.

Storey, A.A., J. M. Ramirez, D. Quiroz, D.V. Burley, D.J. Addison, R. Walter, A.J. Anderson, T.L. Hunt, J.S. Athens, L. Huynen and E. A. Matisoo-Smith 2007. Radiocarbon and DNA evidence for a pre-Columbian introduction of Polynesian chickens to Chile. Proceedings of the National Academy of Sciences 104(25):10335-10339.

Stothert, K.E. 2007. Report on Pottery from Galapagos (including artifacts from the ANU 2005 field season and other collections). San Antonio: The University of Texas.

Stuiver, M. and P. Reimer 1993. Calib.

Suggs, R. 1960. The Island Civilizations of Polynesia. New York: The New American Library.

Suggs, R. C. 1967. A Reanalysis of Galapagos Ceramics Data. Zeitschrift fur Ethnologie 92:239-247.

Summerhayes, G. 2000. Lapita Interaction. Canberra: ANH Publications and the Centre for Archaeological Research.

Terrell, J. E. 1998. The prehistoric Pacific. Archaeology Nov/Dec 1998:56-63.

US Forest Service, Pacific Island Ecosystems at Risk (PIER). Online resource at http://www.hear.org/ pier/ accessed 10/12/07.

van Leeuwen, J., W. van der Knaap and B. Ammann 2007. The native or introduced status of plant species determined by fossil pollen in Galapagos and the Azores In N.R. Catto (ed), XVII INQUA Congress. The tropics: Heat engine of the Quaternary, pp. 430-431. Cairns: Quaternary International.

Wagner, W. L., Herbst, D. R. and Sohmer, S. H. 1999. Manual of the flowering plants of Hawaii. Revised edition. Bernice P. Bishop Museum special publication. Honolulu: University of Hawai'i Press and Bishop Museum Press.

Whistler, W. A. 1988. Checklist of the weed flora of western Polynesia. Technical Paper No. 194, Noumea: South Pacific Commission.

Whitlock, C. and C. Larsen 2001. Charcoal as a fire proxy, In J.P. Smol, H.J.B. Birks and W.M. Last Dordrecht (eds), Tracking Environmental Change Using Lake Sediments. Volume 3: Terrestrial, Algal, and Siliceous Indicators, pp. 75-97. The Netherlands: Kluwer Academic Publishing.

Willis, K.J., M.B. Araujo, K.D. Bennett, B. Figueroa-Rangel, C.A. Froyd and N. Myers 2007. How can a knowledge of the past help to conserve the future? Biodiversity conservation and the relevance of long-term ecological studies. Philosophical Transactions of the Royal Society 362:175-186.

Woram, J. 2005. Charles Darwin Slept Here. Rockville, USA: Rockville Press.

Yen, D. 1974. The Sweet Potato in Oceania: An Essay in Ethnobotany. Honolulu: Bishop Museum Press.

Zolitschka, B., J. Mingram, S.V.D. Gaast, J.H.F. Jansen and R. Naumann 2001. Sediment logging techniques, In W.M. Last and J.P. Smol Dordrecht (eds), Tracking Environmental Change Using Lake Sediments. Volume 1: Basin Analysis, Coring and Chronological Techniques, pp. 137-153.

The Netherlands: Kluwer Academic Publishers 